\title{
LECHOŃ NIEOCZYWISTY
}

\author{
Magdalena GERAGA (Społeczna Akademia Nauk w Lodzi) \\ ORCID: 0000-0003-0851-7912
}

Trudno o biografię pełną większych sprzeczności. Homoseksualista wielbiony przez prawicę. Samobójca pochowany w katolickim obrządku. Zwolennik rozwiązywania konfliktów międzynarodowych przez wojny, który trząsł się ze strachu, uciekając z Francji przed nadchodzącym frontem. Biedny emigrant zajmujący kilka mieszkań. Wielki patriota, który tylko szukał okazji, by wynieść się z Polski na dziesięciolecia. Snob, który nie umiał zachować się przy stole ${ }^{1}$.

Ostatnie zdanie jest, oczywiście, parafrazą Iwaszkiewiczowej opinii: „A w gruncie rzeczy był taki wulgarny. Nie umiał zachować się przy stole, zupę jadał jakoś bokiem, jak pies chłepcze" ${ }^{2}$. Jarosław Iwaszkiewicz nie przepadał za Lechoniem i nie zmienił swej opinii nawet po tragicznym odejściu „Leszutka”, jak nazywali go przyjaciele i znajomi. We wspomnieniach pisał: „Lechoń był rozpieszczony przez wszystkich: przez rodziców, przez kolegów, przez przyjaciół, przez kobiety. Zachowywał się zbyt często jak primadonna i niejedną przykrość sprawiał najbliższym dziwacznością swego zachowania"3. Niechęć była odwzajemniona; Lechoń nie miał o Iwaszkiewiczu lepszego zdania, nazywając go „głupim Jarosławem"4, aportującym Bierutowi ${ }^{5}$ (mając być może na myśli m.in. List do Prezydenta ${ }^{6}$ ). $\mathrm{Z}$ drugiej strony Iwaszkiewicz przyzna, że Lechoń zrobił dla niego dużo, np. wydał po francusku Panny z Wilka i Brzezinę: „Nie lubiliśmy się w gruncie rzeczy z Leszutkiem, ale i bez lubienia się byliśmy przyjaciółmi"”. Ot, i kolejna niejednoznaczność.

\footnotetext{
${ }^{1}$ K. Tomasik, Homobiografie, Warszawa 2014, s. 201.

${ }^{2}$ J. Iwaszkiewicz, O Janie Lechoniu (1962), [w:] tamże, s. 201.

3 J. Iwaszkiewicz, Lechoń (1984), [w:] Wspomnienia o Janie Lechoniu, zebrał i oprac. P. Kądziela, Warszawa 2006, s. 62.

${ }^{4}$ Wpis z 26 marca 1953 r., [w:] J. Lechoń, Dziennik, t. 3 (1 stycznia 1953-30 maja 1956), Warszawa 1993, s. 76.

${ }^{5}$ Wpis z 5 marca 1954 r., [w:] tamże, s. 320.

${ }^{6}$ J. Iwaszkiewicz, List do Prezydenta, wiersz datowany na 18 kwietnia 1952 r., poświęcony 60. rocznicy urodzin Bolesława Bieruta, pierwodruk: Nowa Kultura $1952 \mathrm{nr}$ 16/17; zob.: komentarz Lechonia w liście do Grydzewskiego z 21 maja 1952 r., [w:] M. Grydzewski, J. Lechoń, Listy 1923-1956, t. 2, oprac. B. Dorosz, Warszawa 2006, s. 37.

${ }^{7}$ List Iwaszkiewicza do Grydzewskiego z 10 czerwca 1956 r., [w:] M. Grydzewski, J. Iwaszkiewicz, Listy 1922-1967, oprac. M. Bojanowska, Warszawa 1997, s. 98.
} 
I nieostatnia. Oto bowiem homoseksualista podkochujący się i — być może zaręczony z Wandą Serkowską ${ }^{8}$, siostrą swego kolegi. Mizoginista z gronem zaprzyjaźnionych kobiet. Hipochondryk, zadręczający siebie i innych myślami samobójczymi, potrafiący jednak pisać o nadziei i podtrzymywać na duchu chorego przyjaciela, Rafała Malczewskiego'. Tropów prowadzących do niejednoznacznych interpretacji biografii jest dużo więcej.

Może zatem z powodu tej nieoczywistości „trudno o biografię tak niepełną” choć pisano o nim wiele (wzmożone zainteresowanie, co oczywiste, nastąpiło po samobójczej śmierci 6 czerwca 1956 roku), nie doczekał się Serafinowicz biografii kompletnej. Wychodziły książki skupione na jednym okresie twórczości, np. Jan Lechoń jako redaktor $i$ publicysta $w$ okresie nowojorskim Stanisława J. Kowalskiego ${ }^{10}$ czy Ruchomy na szali wagi. Lechoń homotekstualny Barbary Czarneckiej ${ }^{11}$. Należy tu także odnotować ważne prace Beaty Dorosz ${ }^{12}$, jednak jak dotychczas żaden z badaczy nie podjął się opisania całości życia i twórczości Lechonia.

Amerykański okres życia, czyli czas ostatni, jest dość dobrze udokumentowany za sprawą listów do przyjaciół (między innymi redaktora naczelnego „Wiadomości Literackich”, Mieczysława Grydzewskiego), dziennika, pisanego w latach 1949-1956, oraz wspomnień i wspominek, wydanych rok po śmierci Lechonia ${ }^{13}$. Sam diariusz nie jest pamiętnikiem stricte osobistym i nieprzeznaczonym dla czytelników. Wacław Solski $^{14}$ twierdzi, że nie ma tam prawdziwego Lechonia, a żywy poeta był daleko bardziej interesujący niż jego wspomnienia ${ }^{15}$. Antoni Słonimski natomiast dodaje:

Pozostały po nim trzy grube tomy pamiętników i parę niewielkich tomów poezji. Pamiętniki te są pretensjonalne i nieprawdziwe. W porównaniu ze świetnymi zapiskami Gombrowicza zasmucają pustką intelektualną i anegdotyzmem ${ }^{16}$.

Nie sposób nie wspomnieć w tym miejscu o niechętnym stosunku Witolda Gombrowicza do Lechonia. 11 lutego 1955 roku autor Ferdydurke pisze do Jerzego Giedroycia:

„Kultura” nie powinna tolerować tego, co Grydz wyrabia z Lechoniem. Ostatecznie można by nad tym przejść do porządku, gdyby wieszcz miał najlżejsze kwalifikacje na to stanowisko, gdyby to miało jakiś grunt w opinii. Ale cyniczny proceder Grydza wynika z przeświadczenia, że można sterroryzować opinię, wmówić ludziskom, co się

\footnotetext{
${ }^{8}$ Wanda Serkowska, później Tomaszewska; siostra kolegi Lechonia, Bogdana, córka warszawskiego przemysłowca, Jana Serkowskiego.

${ }^{9}$ Rafał Marceli Ludwik Fortunat Józef Malczewski (1892-1965), syn Jacka Malczewskiego; polski malarz, rysownik, pisarz i felietonista, taternik, narciarz, popularyzator Tatr i tatrzańskich sportów; współpracownik „Wiadomości Literackich”. 1996.

${ }^{10}$ S. J. Kowalski, Jan Lechoń jako redaktor i publicysta w okresie nowojorskim, Lublin

${ }^{11}$ B. Czarnecka, Ruchomy na szali wagi. Lechoń homotekstualny, Torun 2013.

${ }^{12}$ Zob. np.: B. Dorosz (oprac.), Księga gości Jana Lechonia, Torun 1999; taż (oprac.), Lechoń nowojorski: w setna rocznice urodzin poety, Warszawa 1999; taż, Archiwum Jana Lechonia w Polskim Instytucie Naukowym w Nowym Jorku. Redakcja z badań, Pamiętnik Literacki 1999 z. 3.

${ }^{13}$ Zob.: poświęcony Lechoniowi numer Wiadomości - 1957 nr 23 (584)

${ }^{14}$ Wacław Solski (1897-1990), właśc. Jan Pański, prozaik, eseista, działacz polityczny, w młodości związany z SDKPiL, więziony za działalność komunistyczną (z partią rozstał się podczas pobytu w Berlinie w 1928 r.).

${ }^{15}$ W. Solski, Ostatni dzień Jana Lechonia (1985), [w:] Wspomnienia o Janie Lechoniu, s. 319.

${ }^{16}$ A. Słonimski, Jan Lechoń (1973), [w:] Wspomnienia o Janie Lechoniu, s. 44.
} 
chce, i wyznaczyć emigracji wieszcza ukazem, wybrać jakiegoś poecinę i powiedzieć: klękajcie! ${ }^{17}$

A oto co odpisał redaktor „,bydlęcej”," , według Lechonia, „Kultury”, na którego notabene autor Karmazynowego poematu nasłałby chętnie literacką bojówkę, mając nadzieję, iż ta zbiłaby ofiarę „,po dupie” (,nie przecinając skóry” ${ }^{19}$ :

Na Lechonia i na Grydzewskiego nie ma rady i — nie łudźmy się — Grydz z Lechoniem są bardziej w guście rodaków niż my, np. „Kultura” to zawsze jakiś zapaszek żydomasoński, podejrzany, a tu wszystko proste, jasne ${ }^{20}$.

„Poecina”, jak nazywał Gombrowicza Lechoń, miał do autora Ferdydurke i jego literatury stosunek - a jakże — ambiwalentny. W Dzienniku pisze o Transatlantyku jako o historii „,plugawej i cokolwiek śmierdzącej”21, samego Gombrowicza nazywa „,́sintuchem zażenowanym" "22, a w chwilach mniejszego krytycyzmu „spokojnym wariatem o nieubłaganej logice"23. Tuż przed śmiercią zmienia jednak (prawdopodobnie) zdanie, na co wskazuje fragment listu do Gombrowicza. „O pana pracach, o Ferdydurke, o Trans-Atlantyku, myślę z niezmienną przyjemnością, jako o świetnych utworach" ${ }^{24}$. Dokument ten trafia do Grydzewskiego - notabene już po samobójstwie Lechonia — jako ciekawostka i zamknięcie pewnego rozdziału dotyczącego ich trudnej relacji.

Nie mniej nieoczywisty stosunek miał Lechoń do Czesława Miłosza. W listach do Grydzewskiego określa go „,rzadkim gównem”,25, „skursywsynem”26, nową, gorszą odmianą Iwana Karamazowa $^{27}$, w swym diariuszu podważa niejednokrotnie jego talent literacki $^{28}$, a jednak 22 kwietnia 1952 roku śni mu się Miłosz, który wzywa do zgody ${ }^{29}$. Czyżby odezwała się potęga podświadomości? Co ciekawe, w 1935 roku Miłosz zapisuje w Księdze Gości Lechonia: ,„Skończonemu“ poecie hołd od szczeniaka - Czesław Miłosz 29/VI/1935”30, w Abecadle notuje: „Lechoń Jan. Mityczna postać poety

${ }^{17}$ List Gombrowicza do Giedroycia z 11 lutego 1955 r., [w:] J. Giedroyc, W. Gombrowicz, Listy 1950-1969, oprac. A. S. Kowalczyk, Warszawa 2006, s. 189.

${ }^{18}$ List Lechonia do Grydzewskiego z 28 września 1953 r., [w:] M. Grydzewski, J. Lechoń, Listy 1923-1956, t. 2, s. 156.

${ }^{19}$ List Lechonia do Grydzewskiego z 5 października 1953 r., [w:] tamże, s. 163.

${ }^{20}$ List Giedroycia do Gombrowicza z 22 lutego 1955 r., [w:] J. Giedroyc, W. Gombrowicz, Listy 1950-1969, s. 192.

${ }^{21}$ Wpis z 1 marca 1953 r., [w:] J. Lechoń, Dziennik, t. 3, s. 54

${ }^{22}$ Wpis z 20 sierpnia 1953 r., [w:] tamże, s. 191.

${ }^{23}$ Wpis z 28 października 1953 r., [w:] tamże, s. 237.

${ }^{24}$ W. Gombrowicz, Dziennik 1957-1961, Kraków 1986, s. 180. Zob. też: M. Stępień, Witold Gombrowicz wśród polskich emigrantów, [w:] tenże, Wśród emigrantów, Kraków 2007, s. 88-89.

${ }^{25}$ List Lechonia do Grydzewskiego z 4 marca 1948 r., [w:] M. Grydzewski, J. Lechoń, Listy 1923-1956, red. B. Dorosz, t. I, Warszawa 2006, s. 173.

${ }^{26}$ List Lechonia do Grydzewskiego z 8 marca 1952 r., [w:] Listy 1923-1956, t. 2; list Lechonia do Grydzewskiego z 24 marca 1952 r., [w:] tamże, s. 27.

${ }^{27}$ List Lechonia do Grydzewskiego z 13 sierpnia 1954 r., [w:] tamże, s. 266.

${ }^{28}$ Wpis z 9 kwietnia 1950 r., [w:] J. Lechoń, Dziennik, t. 1 (30 sierpnia 1949-31 grudnia 1950), Warszawa 1992, s. 263; wpis z 22 lipca 1955, [w:] J. Lechoń, Dziennik, t. 3, s. 666.

${ }^{29}$ Wpis z 22 kwietnia 1952 r., [w:] J. Lechoń, Dziennik, t. 2 (1 stycznia 1951-31 grudnia 1952), Warszawa 1992, s. 421.

${ }^{30}$ Księga gości Jana Lechonia, oprac. B. Dorosz, Toruń 1999, s. 42. 
mojej młodości”, ${ }^{31}$, w konsekwencji jednak w tym samym dziele określa go „rzekomo genialnym w młodości [...] głupim człowiekiem"32.

O meandrach przyjaźni, trwającej od 1916 roku, z Julianem Tuwimem pisze w swojej książce Beata Dorosz ${ }^{33}$. W skrócie: w 1942 roku Lechoń zrywa z autorem Sokratesa tańczacego wszelkie kontakty, wyrażając tym sprzeciw wobec politycznej postawy i działalności Tuwima. Mimo to w Dzienniku (19 stycznia 1950 roku) notuje: „Wszystko między mną a Tuwimem zerwane na zawsze oprócz poezji. W niej będzie jego ułaskawienie" ${ }^{34}$. Tuż po śmierci Tuwima zaś dodaje wpis:

Umarł Tuwim. Ta wiadomość napełniła mnie czymś, czego nie nazwać inaczej niż solennością — bo też sprawa między nami była tak poważna, że ani jej nie można zakłamać, ani się z niej wykłamać. I teraz nie mogę zapomnieć o tych ostatnich 7 latach — ale pamiętam jeszcze 20 parę lat - mych włóczeń się, milczeń, żartów, ale przede wszystkim jego wierszy. Gdym je pierwszy raz jeszcze przed Czyhaniem na Boga przeczytał - wiedziałem, że nigdy takich nie będę pisał, że jeśli staną się one jedynym wzorem ówczesnego i idącego okresu - będę nie uznany, może wyśmiewany — ale czułem, że w tej nowej obcej mi epoce on jest prawdziwym i w pewnym niepatetycznym sensie wielkim twórcą. [...] Już nie nam go sądzić i szkoda każdego słowa naszego ludzkiego sądu. „Niech Ci lekką będzie, Julku, ta ziemia polska, którąś tak źle, tak głupio, ale naprawdę kochał"35.

Kilka dni później kontynuuje ową myśl w liście do Grydzewskiego, pisząc o „zmąconych uczuciach": wspólistnieniu niechęci do człowieka i podziwu dla artysty ${ }^{36}$.

O trudnych niekiedy relacjach interpersonalnych Lechonia „,Z resztą świata” wspomina znajoma poety, Hanna Mortkowicz-Olczakowa ${ }^{37}$ : „Złośliwość, zawiść, perfidne nieraz plotki, brak koleżeńskiej solidarności, snobizm — to były cechy, którymi pokrywał i kompensował własne twórcze konflikty, największą słabość swojego życiaa,38. Rzeczywiście, pewne fragmenty Dziennika dość literalnie traktują o niekłamanej niechęci, jaką żywił do niektórych osób, połączonej z potrzebą jej zwerbalizowania. Iwaszkiewicz jest według niego głupi ${ }^{39}$, Jastrun to grafoman ${ }^{40}$, Broniewski - pijak $^{41}$, Nałkowska - babski dorobkiewicz ${ }^{42}$, Dąbrowska - krętaczka $^{43}$, Krzywicka - świniolog ${ }^{44}$, nie najlepiej pisze o Czapskim $^{45}$, Terleckim $^{46}$, a George Sand to - jego zdaniem - potworne babsko ${ }^{47}$.

${ }^{31}$ C. Miłosz, Abecadto Miłosza, Kraków 1997, s. 249.

${ }^{32}$ Tamże.

${ }^{33}$ B. Dorosz, Lechoń i Tuwim — dzieje trudnej przyjaźni, Warszawa 2004.

${ }^{34}$ Wpis z 19 stycznia 1950 r., [w:], J. Lechoń, Dziennik, t. 1, s. 188.

${ }^{35}$ Wpis z 28 grudnia 1953 r., [w:], J. Lechoń, Dziennik, t. 3, s. 277.

${ }^{36}$ List Lechonia do Grydzewskiego z 30 grudnia 1953 r., [w:] M. Grydzewski, J. Lechoń, Listy 1923-1956, t. 2, s. 189

${ }^{37}$ Hanna Mortkowicz-Olczakowa (1905-1965), polska poetka i pisarka żydowskiego pochodzenia, autorka wielu utworów dla dzieci i młodzieży. Po wojnie współpracowała z Polskim Radiem.

${ }^{38}$ H. Mortkowicz-Olczakowa, Wspomnienie o Janie Lechoniu (1959), [w:] Wspomnienia o Janie Lechoniu, s. 143.

${ }^{39}$ Wpis z 26 marca 1953 r., [w:] J. Lechoń, Dziennik, t. 3, s. 76.

${ }^{40}$ Wpis z 15 lipca 1951 r., [w:] J. Lechoń, Dziennik, t. 2, s. 188.

${ }^{41}$ Wpis z 24 stycznia 1950 r., [w:] J. Lechoń, Dziennik, t. 1, s. 192.

${ }^{42}$ Wpis z 27 stycznia 1950 r., [w:] tamże, s. 195.

${ }^{43}$ Wpis z 16 grudnia 1955 r., [w:] J. Lechoń, Dziennik, t. 3, s. 784.

${ }^{44}$ Wpis z 21 lutego 1956 r., [w:] tamże, s. 790.

${ }^{45}$ Wpis z 1 października 1949 r., [w:] J. Lechoń, Dziennik, t. 1, s. 67.

${ }^{46}$ Wpis z 18 stycznia 1950 r., [w:] tamże, s. 187; Tymon Terlecki (1905-2000), nestor polskiej literatury emigracyjnej, krytyk literacki i teatralny, eseista i organizator życia naukowego i literackiego w Anglii oraz Stanach Zjednoczonych 
Przyjaciel Serafinowicza, Zdzisław Czemański ${ }^{48}$, Irena Lorentowicz ${ }^{49}$ oraz Krzysztof Tomasik ${ }^{50}$ ową ,słabość” nazywają eufemistycznie tęsknotą do plotek. Rzeczywiście, w datowanym na 21 maja 1952 roku liście do Grydzewskiego - Lechoń domaga się nowinek-,,smakowitości" "51 , a w czerwcu tegoż roku solennie za nie dziękuje ${ }^{52}$.

Z drugiej strony nie sposób nie wspomnieć o pomocy, którą Lechoń oferuje Rafałowi Malczewskiemu, o trwającej całe lata przedziwnej relacji jednostronnego wsparcia, opartej na zbieraniu funduszy, organizowaniu wystaw i pocieszaniu coraz bardziej chorego i pogrążonego w rozpaczy malarza. Już w 1965 roku, czyli po śmierci drugiego z artystów, zachowaną korespondencję wysyła Grydzewskiemu wdowa po Malczewskim, Zofia, opatrując ją znamiennym komentarzem:

Drogi Panie Mieciu,

w załączeniu przesyłam 16 listów Lechonia, które pisywał do Rafała w latach 1952-54, podtrzymując go na duchu i namawiając do pisania. W lutym 1952 Rafał dostał po raz pierwszy zaślepnięcia w lewym oku, co już do końca się powtarzało i wprawiało go w panikę. Wtedy załamał się zupełnie i na dwa lata z okładem przestał malować. Myślał, że ślepnie.

Wtedy Leszek namówił go do pisania i Rafał zaczął pisać jak szalony, a od wojny prawie że nie pisał wcale. Leszek, jak Pan zobaczy z tych listów, był nadzwyczajny, a listy są wspaniałe. Może było więcej, ale na razie tylko tyle znalazłam ${ }^{53}$.

Lechoń, który jako dwudziestodwulatek próbował odebrać sobie życie ${ }^{54}$, niedługo przed kolejną, tym razem udaną próbą samobójczą — przedstawia w listach do Malczewskiego programowy, nieco sztuczny optymizm, spod którego — jak wspomina sam malarz wyłaniał się niekiedy mrok ${ }^{55}$. W 1952 roku Lechoń pisał: „Wiem, jak Panu ciężko — ale niech mi Pan wierzy, że każdy ma nieszczęście, które wydaje mu się nie do zniesienia. To głupio brzmi, ale Pan jest jeden z tych wybranych, którym Pan Bóg dał w sobie samym źródło radości, pociech i nadziei",56. W 1953 roku przekonuje, że życie nigdy nie jest tak złe, aby z niego zrezygnować ${ }^{57}$; w 1954 roku ton listów jest podobny:

Niech Pan przede wszystkim odwróci się od tych cytat, które same już mogą być dowodem, jakie życie gotuje niespodzianki, bo gdym te wiersze pisał, były one moją naj-

${ }^{47}$ Wpis z 4 maja 1952 r., [w:] J. Lechoń, Dziennik, t. 2, s. 431.

${ }^{48}$ Z. Czermański, O Leszku, [w:] Wspomnienia o Janie Lechoniu, s. 111; Zdzisław Czermański (1901-1970), prozaik, artysta malarz, karykaturzysta; współpracownik „Wiadomości Literackich".

49 I. Lorentowicz, Odludki i poeta (1972), [w:] Wspomnienia, s. 250; Irena Lorentowicz (1908-1985), malarka, scenograf; współpracowała z najważniejszymi scenami operowymi w kraju.

${ }^{50}$ K. Tomasik, Homobiografie, s. 213.

${ }^{51}$ List Lechonia do Grydzewskiego z 21 maja 1952 r., [w:] M. Grydzewski, J. Lechoń, Listy 1923-1956, t. 2, s. 37.

${ }^{52}$ List Lechonia do Grydzewskiego sprzed 6 czerwca 1952 r., [w:] tamże, s. 45.

${ }^{53}$ Archiwum Emigracji, Archiwum „Wiadomości” (dalej: AE AW), sygn. AE/AW/CXCIV, Korespondencja, list Malczewskiej do Grydzewskiego z 14 września 1965 r.

${ }^{54}$ Zob.: K. Wierzyński, Z „Pamiętnika poety” (1991), [w:] Wspomnienia o Lechoniu, s. 47-48.

${ }^{55}$ B. Dorosz, ,, Coraz trudniej żyć, a umrzé strach”. O dramatycznej przyjaźni poety i malarza, wstęp do: J. Lechoń, Z. i R. Malczewscy, Coraz trudniej żyć, a umrzeć strach. Listy 19521955, Biblioteka Więzi, t. 215, Warszawa 2008, s. 22; R. Malczewski, Śpiew (1957), [w]: Wspomnienia o Janie Lechoniu, s. 234.

${ }^{56}$ List Lechonia do Malczewskiego z 24 maja 1952 r., [w:] J. Lechoń, Z. i R. Malczewscy, Coraz trudniej żyć, a umrzé́ strach, s. 33.

${ }^{57}$ List Lechonia do Malczewskiego z 12 maja 1953 r., [w:] tamże, s. 82. 
głębszą prawdą, po czym przeżyłem trzydzieści lat i jestem szczęśliwy, żem je przeży ${ }^{58}$. Błagam Pana - niech Pan tę siłę, którą się Pan pcha w rozpacz, zużyje na nadzieję, wiarę i miłość - wcale nie takie głupie cnoty. Zobaczy Pan, że to możliwe i że warto $^{59}$.

Dwa lata później Lechoń odbiera sobie życie.

Niejednokrotnie w Dzienniku pojawia się opis trudów życia Malczewskiego; bez zniecierpliwienia i z godną podziwu empatią autor thumaczy potencjalnym czytelnikom problemy malarza ${ }^{60}$; ten zaś, zmęczony samym sobą, pisze, że „nie jest z żelaza, tylko z gówna"61 , oczekując, a jakże, słów wsparcia. Kilka dni po śmierci Lechonia Malczewski wysyła do Grydzewskiego list:

Kochany Mieciu,

[...] Jesteśmy wstrząśnięci wieścią o śmierci Lechonia, którą wczoraj wieczorem otrzymaliśmy. $\mathrm{Na}$ wieczorze Hemara. Bardzo wiele zawdzięczam $\mathrm{Mu}$ — pomógł mi wydźwigać się po chorobie, namówił do pisania. Zorganizował albo raczej zachęcił chętne panie do zorganizowania wieczoru w New-Yorku dla mnie - chorego wówczas zupełnie, ułatwił zdobytą forsą leczenie i przeżycie jakiegoś okresu bez obłędnego biegania za forsą. Pisał listy do mnie pełne słów zachęty i zrozumienia - tej paniki wewnętrznej, koszmaru, pasji samozniszczenia. Lękam się, że sam jej uległ ${ }^{62}$.

Wspomniany w liście Marian Hemar to postać nietuzinkowa i dla Lechonia ważna. Jeszcze kilka miesięcy przed opisywanymi wyżej tragicznymi wydarzeniami Lechoń notuje w Dzienniku: „Brawo, Hemarku! Inteligentny, wzruszający, przydatny Polsce”63, określa go jako płodnego, pomysłowego, muzykalnego, z literacką klasą i rzetelnością przekonań politycznych"64, artystę, który doszedł do szczytu ${ }^{65}$, choć jednocześnie jak wspomina Czermański, składając to na karb depresji — zazdrościł mu sukcesów, przeżywając je jak osobiste niepowodzenie ${ }^{66}$. Mimo to - konsekwentnie oczarowany jego talentem - miesiąc przed śmiercią Lechoń pisze:

„Kabaret” Hemara — akurat mi było do kabaretu! Ale zrozumiałem, że był świetny, oczywiście nie wszystkie numery, i były niektóre za rozwlekłe i za „poetyczne”. Ale Hemar jest w tym rodzaju jedynym autorem na świecie, jako płodność, pomysłowość, muzykalność, klasa literacka i do tego jeszcze prawdziwość i rzetelność przekonań politycznych $[\ldots]^{67}$.

Niewątpliwie sympatia Lechonia była odwzajemniona. Mimo to — a jakże! — i w tej znajomości kryje się nieoczywistość, w tym przypadku — niezamierzony zgrzyt inter-

${ }^{58}$ Chodzi o utwory z tomu Srebrne i czarne (1924), stanowiące pokłosie samobójczej próby w $1921 \mathrm{r}$.

${ }^{59}$ List Lechonia do Malczewskiego z 18 maja 1954 r., [w:] J. Lechoń, Z. i R. Malczewscy, Coraz trudniej żyć, a umrzeć strach, s. 140.

${ }^{60}$ Wpis z 9 czerwca 1953 r., [w:] J. Lechoń, Dziennik, t. 3, s. 138; wpis z 27 września 1954 r., [w:] tamże, s. 467.

${ }^{61}$ List Malczewskiego do Lechonia z 15 kwietnia 1954 r., [w:] J. Lechoń, Z. i R. Malczewscy, Coraz trudniej żyć, a umrzeć strach, s. 137.

${ }_{62} \mathrm{AE}$ AW, sygn. AE/AW/CXCIV, Korespondencja, list Malczewskiego do Grydzewskiego z 8 czerwca $1956 \mathrm{r}$.

${ }^{63}$ Wpis z 28 kwietnia 1956 r., [w:] J. Lechoń, Dziennik, t. 3, s. 832.

${ }^{64}$ Wpis z 27 maja 1956 r., [w:] tamże, s. 851.

${ }^{65}$ Wpis z 19 kwietnia 1956 r., [w:] tamże, s. 827.

${ }^{66} \mathrm{AE}$ AW, sygn. AE/AW/XLII, Korespondencja, list Czermańskiego do Grydzewskiego z 14 czerwca $1956 \mathrm{r}$.

${ }^{67}$ Wpis z 27 maja 1956 r., [w:] J. Lechoń, Dziennik, t. 3, s. 851. 
pretacyjny. W (niestety niedatowanym, napisanym jednak z pewnością tuż po śmierci Lechonia) liście Czermańskiego do Grydzewskiego, czytamy:

Do Redaktora Wiadomości

Po przeczytaniu wspomnienia Hemara o Lechoniu w nr 538 „Wiadomości” mniemam, że Hemar upiekł przy tej okazji tragicznej swoją własną pieczeń dla mnie osobiście niesmaczną. Idzie mi głównie o słowa poniższe: „Do tak niedawna byliśmy obaj młodzi, wciąż najmłodsi z naszego pisarskiego pokolenia, - między nim a mną były tylko dwa lata różnicy wieku, - i nagle wyszło nam na to, że obaj jesteśmy już niedobitkami, że nas tak mało zostało, że teraz już tylko o to chodzi, żeby „,coś jeszcze zrobić przed tą z...aną śmiercią", jak Leszkowi powiedział Artur Rubinstein, a on powtórzył mnie". Z tych słów Hemara mógłby ktoś sądzić — ktoś, kto czasów owych i historii grupy poetyckiej Skamandra nie zna — że Hemar istotnie do pisarskiego pokolenia Lechonia należał. Ale ktoś, kto czasy owe pamięta, i zna twórczość Lechonia i Hemara, wie, że tak nie było, że wtedy, kiedy Lechoń był już sławny, wydawszy swój Karmazynowy Poemat, i za pan brat chodził po Warszawie nie tylko z Kolegami po piórze swego pokolenia - ze Słonimskim, Wierzyńskim i Tuwimem - ale też z wszystkimi niemal wielkościami pokolenia poprzedniego - Hemar, będący wówczas chłopcem, biegał po Lwowie luzem albo w grupie do dziś dnia nikomu nieznanej ${ }^{68}$.

Czy atak ów jest uzasadniony? Nie sądzę. Rzeczywiście, Karmazynowy poemat ukazuje się w 1920 roku, Hemar przeprowadza się do stolicy pięć lat później, jednak już od 1925 roku współpracuje ściśle ze Skamandrytami. W maju 1926 roku wystawia wraz z Lechoniem, Tuwimem i Słonimskim Pierwsza warszawska szopkę ${ }^{69}$, w 1938 roku żegna na dworcu - wraz z całą niemal „Małą Ziemiańską" - wyjeżdżającego do ambasady w Rzymie generała Wieniawę ${ }^{70}$, jest stałym bywalcem Skamandryckiego pięterka ${ }^{71}$, a także współtworzy teatrzyk „Qui pro quo”, „Bandę” i „Cyrulika Warszawskiego”.

Jak się można domyślać, Grydzewski, otrzymawszy korespondencję, oponuje i tonuje nastroje. W kolejnym liście Czermańskiego, datowanym na 2 września 1956 roku, czytamy zatem:

Drogi Mieciu,

tego, co w liście do redaktora „Wiadomości” napisałem o Hemarze nie cofam, ale też nie upierałbym się przy tem, że ten list powinien być opublikowany, bo skoroś to, com napisał, zobaczył od strony wielkiej i niezasłużonej przykrości, jaką bym wyrządził, to nie ma już o czem gadać. Muszę zgodzić się z tem, że słusznem jest zbić zarzut niepoparty niezbitymi dowodami. Zrobiłeś to i zgodzę się z tem.

To samo wrażenie, że Hemar o wiele za dużo i w sposób nieskromny mówi o sobie, miałem, czytając jego wspomnienie o Tuwimie (w Wiadomościach) i to samo wrażenie (w obu wypadkach) odniosło kilka osób, z którymi tu na ten temat się zgadałem. Dobrze rozumiem, że przynależność do tego samego pokolenia nie oznacza tej samej rangi pisarskiej. Idzie o to właśnie, że ja i każda z tych osób, którą to i owo we wspomnieniach Hemara raziło, przyuważyliśmy, że Hemar składa niektóre zdania w ten sposób, aby z nich wynikało, że był on w tym samym szeregu i jeżeli nie w tej samej to prawie w tej samej randze pisarskiej co Leszek. Że ten efekt chciał osiągnąć to jest oczywiście tylko kwestia tylko mojego wrażenia, ale tak silnego jak pewność oparta na dowodach.

Żeby nie było wątpliwości: pieczeniem pieczeni nazywam w tym wypadku chęć wywyższania się — skok wzwyż - który, powtarzam, nie tylko mnie raził. Rzecz do

${ }^{68} \mathrm{AE}$ AW, sygn. AE/AW/XLII, Korespondencja, list Czermańskiego do Grydzewskiego (bez daty).

\footnotetext{
${ }^{69}$ L. Sadkowska-Mokkas, Warszawa skamandrytów, Warszawa 2016, s. 115.

${ }^{70}$ Tamże, s. 123.

${ }^{71}$ Tamże, s. 139.
} 
uznania - czy trzeba było głos w tej materii zabierać. Mogę zgodzić się z tem, że wystarczyłoby pokrzywić się na Hemara przy stoliku kawiarnianym, a nie w druku (w większości wypadków zabierający głos w druku mogliby tego nie zrobić). Poza tym mogę powiedzieć, że jestem admiratorem Hemara jako satyryka i że na jego wieczorze w N. Yorku świetnie się bawiłem.

Będę się starał przysłać Ci podobizn Leszka jak najwięcej.

Ściskam Cię serdecznie,

Zdzisław Czermański ${ }^{72}$

Niejednoznaczność Lechoniowych relacji nie umiera, jak widać, wraz z poetą. Wspomniany już Tomasik, łagodząc niejako ocenę charakteru Serafinowicza ${ }^{73}$, wysuwa jednocześnie tezę, iż Lechoń był mizoginistą. Na dowód tego przytacza fragment z Dziennika: „Bij zawsze twoją żonę, nawet jeżeli nie wiesz dlaczego. Bo ona wie na pewno" "74; autor Homobiografii zapomina jednak dodać, że Lechoń cytuje tu „przysłowie wschodnie”, nie dodając notabene żadnego komentarza. Mizoginistyczna i atawistyczna jest natomiast, według mnie, autorska wypowiedź Lechonia: „Kobiety mają instynkt tego, co jest dla nich dobre - jak zwierzęta. Jeśli pojawia się w towarzystwie kobieta piękniejsza od innych, tamte syczą jak węże i od razu łączą się ze sobą przeciw niej jak zagrożone pszczoły czy mrówki",75.

Czy zatem Lechoń nie cenił kobiet? Otóż i to nie jest jednoznaczne. Wystarczy sięgnąć do książki Felicji Lilpop-Krance Powroty ${ }^{76}$, której obszerne fragmenty traktują o przyjaźni autorki z Lechoniem, a także fragmentów Dziennika, pisanych na kilka dni przed śmiercią, aby przeczytać:

O tyle dziś lepiej, że wczoraj był jeden z najgorszych dni w życiu. I sam się sobie dziwię, że dzisiaj miałem parę godzin zapomnienia. I że jako tako mówiłem na otwarciu Bratniej Pomocy.

Przyjaźń ludzka, serce, cóż to za siła! Parę słów Jadzi Smosarskiej ${ }^{77}$, czuła grzeczność Zygmunta ${ }^{78}$, dobry uśmiech Zosi Korbońskiej ${ }^{79}$, warszawska solidarność Neli Rubinstein $^{80}$, pozwoliły mi przeżyć ten dzień, zdawałoby się nie do przeżycia ${ }^{81}$.

${ }^{72}$ AE AW, sygn. AE/AW/XLII, Korespondencja, list Czermańskiego do Grydzewskiego z 2 września $1956 \mathrm{r}$.

${ }^{73}$ K. Tomasik, Homobiografie, s. 213.

${ }^{74}$ Wpis z 3 kwietnia 1953 r., [w:] J. Lechoń, Dziennik, t. 3, s. 106.

${ }^{75}$ Wpis z 23 marca 1953 r., [w:] tamże, s. 72.

${ }^{76}$ F. Lilpop-Krance, Powroty, Warszawa 2013; Felicja Lilpop-Krance (1908-1993), malarka, córka znanego architekta Franciszka Lilpopa, żona pianisty Kazimierza Kranca.

77 Jadwiga Filipina Smosarska (1898-1971), polska aktorka teatralna i filmowa. Największa gwiazda polskiego kina w okresie dwudziestolecia międzywojennego. W 1938 r. odznaczona Złotym Krzyżem Zasługi: „w uznaniu zasług położonych na polu krzewienia polskiej kultury filmowej". We wrześniu 1939 r. wyjechała wraz z mężem do krewnych na Litwę. W tym samym roku dotarli do Stanów Zjednoczonych. Tam zajęła się pracą społeczną wśród Polonii. W 1970 r. wróciła wraz z mężem do Polski. Umiera niecały rok później.

${ }^{78}$ Zygmunt Protassewicz (1899-1991), inżynier budownictwa lądowego. Od 26 lutego 1935 r. mąż Jadwigi Smosarskiej. W latach 1918-1920 podchorąży 201 pułku szwoleżerów. Za udział w wojnie polsko- bolszewickiej został odznaczony Krzyżem Srebrnym Orderu Wojskowego Virtuti Militari i Krzyżem Walecznych, a ponadto Medalem Niepodległości

${ }^{79}$ Zofia Korbońska z domu Ristau (1915-2000), polska działaczka niepodległościowa. Żona i najbliższa współpracowniczka Stefana Korbońskiego

${ }^{80}$ Aniela (Nela) Rubinstein (1908-2001), córka kompozytora i dyrygenta, Emila Młynarskiego, żona Artura Rubinsteina.

${ }^{81}$ Wpis z 28 maja 1956 r., [w:] J. Lechoń, Dziennik, t. 3, s. 851. 
Nela, jak wynika z relacji jej męża, Artura Rubinsteina, znała i ceniła Lechonia: jako poetę i przyjaciela ${ }^{82}$.

O przyjacielskich relacjach ze Smosarską wspomina natomiast w Dziennikach sam autor. Wdzięczny jest jej za gościnę, w której pokłada nadzieję na powrót weny twórczej; dobrodziejstwo ciszy i świeżego powietrza sprawia jednak, że ze zdwojoną siłą obawia się powrotu do domu, samotności, zaduchu, hałasu ${ }^{83}$. Sympatia, którą darzył Smosarską (a właściwie Protassewicz) Lechoń, była odwzajemniona, wystarczy sięgnąć do pełnej szacunku i delikatności korespondencji, opublikowanej w książce Skazane na zapomnienie. Aktorki filmowe na emigracji ${ }^{84}$. Kilka miesięcy po śmierci Lechonia Smosarska pisze w liście do Grudzewskiego:

Drogi Panie Mieciu [...] Nie mogę jeszcze dotychczas pogodzić się z tragicznym odejściem Leszka. Zawsze cieszyliśmy się na Jego przyjazd do nas. Mimo Jego depresyjnych nastrojów i ciągłych myśli o śmierci miał okresy tak nieprawdopodobnego humoru albo raczej dowcipu, że zaśmiewałam się ku Jego radości, wiedział, że jestem dobrym odbiornikiem na dowcipy, dlatego chętnie mi je sypał. Przez ostatnich kilka tygodni robiliśmy co było w naszej mocy, aby wyrwać Go z tego strasznego nerwowego napięcia. Na wieczorze Hemara w trakcie antraktu schwycił mnie za ręce i rozpychając mojemi plecami publiczność wtłoczył mnie omal w ścianę i z przerażonym wyrazem twarzy powiedział mi: „Jadziu, ja sobie odbiorę życie”. Chciałam go zatrzymać, ale wyrwał mi się i zniknął w thumie, na próżno czekaliśmy po teatrze na niego, nie mogliśmy go znaleźć. Zastaliśmy go następnego dnia i poszliśmy razem na lunch. Chcieliśmy Go zabrać ze sobą na wieś, obiecał, że jak załatwi swoje różne sprawy, przyjedzie, i jak mi później mówili znajomi, miał szczerą intencję. Nie przyjechał. Pojechaliśmy w tydzień znów do New-Yorku, był w okropnym stanie, połykał ciągle jakieś uspokajające pastylki, a gdy się na ulicy żegnaliśmy, bardzo mnie czule obejmował i całował.

Ten gorętszy tym razem objaw czułości przypisałam wówczas chwilowemu Leszkowemu humorkowi, nie przeczuwając, że to miało być pożegnanie na zawsze. Ta myśl samobójcza chodziła za Nim stale, jak się okazuje, nawet od młodzieńczych lat, o czym wspomina Magdalena Samozwaniec w swych wspomnieniach [Maria i Magdalena, przyp. M. G. ]. Przed śmiercią napisał nam taką dedykację na książce Mickiewicz: ,,Królowej Jadwidze i Jej dzielnemu Małżonkowi - Litwinowi ze słowami wdzięczności za tyle dobroci i łaskawości doznanej na Królewskim dworze — sługa Jan Lechoń". Innym razem znów „Mojej ukochanej uczennicy Jadzi Smosarskiej prof. J.L.”. Nie wiem, czemu uczennicy, ale pewnie dlatego, że czasami pytałam Go, jakiego określenia byłoby najlepiej użyć w tym czy innym wypadku ${ }^{85}$.

Kobiet w życiu Lechonia było dużo więcej; jakkolwiek trudno polemizować z tezą o homoseksualizmie Serafinowicza, niezaprzeczalnie lubił otaczać się płcią przeciwną. Ba! Były i takie panie, jak chociażby Stanisława Nowicka ${ }^{86}$, które przypominały sobie, że oświadczył się ich wspólnej znajomej, wdowie po ministrze; ta jednak odmówiła. Ponadto, kontynuuje Nowicka, o p. Jackowskiej mówił jak o świętości i zakochał się

${ }^{82}$ A. Rubinstein, Wielki poeta, przyjaciel i brat, Wiadomości (Londyn) $1956 \mathrm{nr} 31$.

${ }^{83}$ Wpis z 21 czerwca 1953 r., [w:] J. Lechoń, Dziennik, t. 3, s. 169; wpis z 22 września 1953 r., [w:] tamże, s. 214; wpis z 14 lipca 1954 r., [w:] tamże, s. 417; wpis z 3 lipca 1955 r., [w:] tamże, s. 654.

${ }^{84}$ G. Rogowski, Jadwiga Smosarska. Abdykacja królowej polskiego filmu, [w:] tenże, Skazane na zapomnienie. Polskie aktorki filmowe na emigracji, Warszawa 2017, s. 251-269.

${ }^{85} \mathrm{AE}$ AW, sygn. AE/AW/CCXCI, Korespondencja, list Smosarskiej do Grydzewskiego z 12 lutego $1957 \mathrm{r}$.

${ }^{86}$ Stanisława Nowicka (1905-1990), polska śpiewaczka, aktorka filmowa, teatralna i tancerka kabaretowa. 
w córce Skłodowskiej ${ }^{87}$. To ostatnie potwierdza (sic!) zresztą sam Lechoń w Dzienniku, komentując doniesienia o ślubie Ewy: wyszła „za jakiegoś niby ważnego Amerykanina francuskiego pochodzenia" ${ }^{\text {88 }}$. Żałuje, że to nie on jest tym wybrankiem, miał bowiem nadzieję na połączenie dusz (sic!).

Tadeusz Katelbach z kolei sugerował, iż pierwszą miłością poety była wspomniana już Wanda Serkowska:

Panna Wanda byłą przystojną brunetką, bardzo inteligentną i na swój wiek bardzo opanowaną. Od Kazi [Goldbaumówny, przyp. M. G. ] dowiedziałem się, że Leszek kocha się w niej na zabój. Kiedy zapytałem pannę Wandę, czy wyznał jej swą miłość, odpowiedziała, że tak i wskazała różę, którą z sobą przyniosła. „Ta róża to prezent od niego. Jestem w bardzo kłopotliwej sytuacji. Uwielbiam go jako poetę, lubię z nim rozmawiać, ale nie mogę odwzajemnić mu się uczuciem, jakim mnie darzy”. Zdaje mi się, że nieszczęśliwa miłość do Wandy Serkowskiej — była wielkim zawodem w życiu młodego poety. Przeżywał go długo ${ }^{89}$.

Oto zadedykowany jej wiersz:

Na niebo wpływają białych chmurek żagle

Od twojej płynie strony niebieska fregata

Nie do mnie, nie do ciebie. I poczułem nagle

Że już nigdy nie będzie, jak zeszłego lata

Nie przyjdzie księżycowa $\mathrm{i}$ w twoim ogrodzie

Na srebrnej trawie cienie ułoży ogromne.

A później będzie koła rysować na wodzie

Gdy będziesz szła ogrodem nie ze mną nie do mnie $^{90}$.

O Wandzie, która skradła Lechoniowi serce, wspomina także Hanna Mortkowicz-Olczakowa ${ }^{91}$ oraz przyjaciel poety, Kazimierz Wierzyński:

A przechodził cierpienia często i dotkliwie. Jednym z nich była miłość do Wandy Serkowskiej, osoby wyjątkowej urody, o przepięknych oczach i nieskazitelnej, oliwkowej cerze Hiszpanek. Nie umiał dać sobie rady z tym uczuciem, mimo przychylności panny i właściwie ukrywał je przed nami. Można dziś o tym mówić — oboje nie żyją. Inne cierpienia, głównie na tle nerwowym, objawiły się później ${ }^{92}$.

Sam Lechoń 24 lutego 1923 roku pisze o niej w liście do Anny Iwaszkiewiczowej ${ }^{93}$ :

${ }^{87}$ Nowicka sugeruje, że Lechoń był zadurzony w Irenie Curie, w rzeczywistości chodziło o Ewę, siostrę Ireny. S. Nowicka, Ostatni weekend Lechonia (1982), Wspomnienia o Janie Lechoniu, s. 312; Ève Curie Labouisse (1904-2007), francusko-amerykańska pisarka, dziennikarka, pianistka i polityk. Córka Marii Skłodowskiej-Curie i Francuza Pierre'a Curie.

${ }^{88}$ Wpis z 19 listopada 1954 r., [w:] J. Lechoń, Dziennik, t. 3, s. 505.

89 T. Katelbach, Wspomnienie o Lechoniu (1956), [w:] Wspomnienia o Janie Lechoniu, s. 36 .

${ }^{90}$ Wiersz ten został wydany w 1924 r., wszedł w skład tomu Srebrne i czarne.

${ }^{91}$ H. Mortkowicz-Olczakowa, Wspomnienie o Janie Lechoniu (1959), [w:] Wspomnienia o Janie Lechoniu, s. 141.

${ }^{92}$ K. Wierzyński, Z „Pamiętnika poety”, (1991), [w:] Wspomnienia o Lechoniu, s. 47.

${ }^{93}$ Anna Iwaszkiewiczowa, z domu Lilpop, pseud. Adam Podkowiński (1897-1979), polska pisarka i tłumaczka, żona pisarza Jarosława Iwaszkiewicza. Autorka Dzienników $i$ wspomnień. W czasie okupacji pomagała polskim Żydom, organizując ucieczki z getta i ukrywając ich w Stawisku. Za tę działalność została 2 stycznia 1988 r. wraz z mężem uhonorowana medalem Sprawiedliwy wśród Narodów Świata. 
Opuściło mnie szczęście — najczęściej odchodzi ono od nas raz na zawsze, mówią o nas wtenczas, żeśmy się zmarnowali. Bardzo, bardzo piękna kobieta, bardzo czuła, bardzo szlachetna, bardzo godna, potrzebuje teraz mnie silnego, gotowego do życia, mam być jej wcielonym złudzeniem - a myślę, że nigdy nie byłem bardziej do tego niezdolny. Nie ma Pani pojęcia, jak mi jest ciężko, ile razy myślę o W.S., biorąc na rozum, sprawa nie powinna być bardziej zawikłana niż Jarosława i Pani — a tak bardzo nie wierzę, abym mógł się zmienić na lepsze. Czuje Pani chyba, że to jest konieczne ${ }^{94}$.

Wiele lat później, w liście do Grydzewskiego, datowanym na 3 marca 1952 roku, a także kolejnym, pisanym tydzień później, wspomina o niej z czułością i troską ${ }^{95}$. Martwi się o jej zdrowie (prawdopodobnie Wanda ma anemię); dodatkowo ma poczucie winy — uważa, że wiele lat temu ją unieszczęśliwił. O tym, że ma to związek z życiem uczuciowym, świadczy zestawienie niemalże w jednej korespondencyjnej linii znajomości z nim (autorem), przedwcześnie zmarłym narzeczonym, Stanisławem Małagowskim $^{96}$ oraz mężem, Tadeuszem Tomaszewskim, którego notabene określa jako „absolutną dupę”, od którego ucieka — nie mogąc się z nim pogodzić — „bardzo podobno udany syn" "97.

Jakkolwiek nieszczęśliwa miłość homoseksualnego mizoginisty może wydawać się interesująca, to z legendą ową mierzy się syn pani Wandy, Jan Tomaszewski ${ }^{98}$, publikując w „Życiu Warszawy” list o jednoznacznym tytule: Jan Lechoń nie byt zaręczony z Wanda Serkowską ${ }^{99}$.

Z samą ideą miłości konfrontuje się Lechoń niejednokrotnie, choćby podczas rozmowy z Czermańskim, przekonanym, że szczęśliwa miłość jest chlebem powszednim:

Na dnie miłości leży poczucie końca, zaprzeczenie nieśmiertelności, która jest naszym celem. I właśnie do tej strasznej prawdy można się „,dokochać”. A wtedy ucieka się od miłości. I rozumiem, że wtedy może nastąpić podział — na wiersze i na dziwki ${ }^{100}$.

Albo na miłość ,jedyną" i jej kompanów. Z Aubreyem Johnstonem ${ }^{101}$, którego w jednym z listów pozdrawia Smosarska (,on taki serdeczny i dobrze wychowany młodzieniec"102), łączy go związek długi, stały, acz niemonogamiczny. Co prawda tylko Aubreya nazywa Lechoń „najdroższą osobą " ${ }^{103}$, wyznaje mu miłość, współcierpi i wydaje się, że staje się dzięki niemu mniej samotny ${ }^{104}$ :

${ }^{94}$ Listy Lechonia do Anny i Jarosława Iwaszkiewiczów, Życie Literackie $1982 \mathrm{nr} 1$.

${ }^{95}$ List Lechonia do Grydzewskiego z 3 marca 1952 r., [w:] M. Grydzewski, J. Lechoń, Listy 1923-1956, t. 2, s. 18; list Lechonia do Grydzewskiego z 10 marca 1952 r., [w:] tamże, s. 23.

${ }^{96}$ Stanisław Małagowski (1894-1919), brat Zofii Wańkowiczowej, porucznik Wojska Polskiego, poległ na froncie w wojnie polsko-bolszewickiej.

${ }^{97}$ List Lechonia do Grydzewskiego z 3 marca 1952 r., [w:] M. Grydzewski, J. Lechoń, Listy $1923-1956$, t. 2, s. 18.

${ }^{98}$ Tadeusz Tomaszewski (1894-1967), pułkownik Wojska Polskiego, komendant obozów byłych jeńców polskich na terenie Bawarii. Po demobilizacji w 1948 r. osiedlił się w Londynie i prowadził działalność w kołach kombatanckich.

99 Życie Warszawy $1996 \mathrm{nr}$ z 6-7 lipca, dodatek.

${ }^{100}$ Wpis z 12 września 1953 r., [w:] J. Lechoń, Dziennik, t. 3, s. 208.

101 Aubrey Johnston, partner Lechonia, w latach 50. Pracownik American Broadcasting Corporation. Zob.: B. Dorosz, Nowojorskie tajemnice życia i śmierci Jana Lechonia, Teksty Drugie 2004 nr 3, s. 196-200.

${ }_{102}$ G. Rogowski, Jadwiga Smosarska. Abdykacja królowej polskiego filmu, s. 261.

${ }^{103}$ Wpis z 1 stycznia 1953 r., [w:] J. Lechoń, Dziennik, t. 3, s. 5; wpis 23 marca 1953 r., [w:] tamże, s. 75; wpis z 15 kwietnia 1953 r., [w:] tamże, s. 93; wpis z 16 maja 1953 r., [w:] tamże, s. 119; wpis z 13 sierpnia 1953 r., [w:] tamże, s. 185; wpis z 14 sierpnia 1953 r., 
List od „najdroższej osoby”. Nie ma chwili w mym życiu, w której bym nie pragnął zmienić jej życie, dać jej życie, dać jej to, co jej się tak bardzo należy. Mówi się, że nasza wola wszystko może. Otóż moja wola nic tutaj nie może poradzić przeciw spiskowi przypadków, okrucieństw i ironii życia. To nie żadne wykręty, tylko prawda bezlitosna, przeciw której nie przestaję się buntować. Dzisiaj cały dzień czułem w sobie wściekłość tego buntu ${ }^{105}$,

to jednak pojawia się niekiedy wzmianka o czymś przelotnym: „[...] miałem »romans«, który mnie od paru dni omijał i po którym pozostało miłe zmęczenie i postanowienie, aby jutro, mówiąc stylem praojców, służyć Apollinowi, nie Wenerze" ${ }^{\text {"106 }}$. Kilka miesięcy wcześniej wspomina natomiast mimochodem o niejakiej „N”, która odrzuciła Lechoniowe zaloty, ale — namyśliwszy się — łaknie romansu ${ }^{107}$, a 15 kwietnia 1956 roku wytrzymuje bezsenną noc tylko dzięki Gabrieli ${ }^{108}$.

Gdzieś pomiędzy „najdroższą osobą” a bezimiennymi bohaterami wpisów sytuuje się Julek Kamler: opowieść o pełnej żalów i niedomówień znajomości z nim kończy się miłosnym wyznaniem Serafinowicza ${ }^{109}$. Kolejną ważną, choć „nie najważniejszą” osobą, jest enigmatyczna Libra. Kim był(a), tego nawet czołowej badaczce Lechoniowej spuścizny, Barbarze Dorosz, nie udało się ustalić ${ }^{110}$. Wzmianek o tej niejednoznacznej znajomości odnajdziemy w Dzienniku całkiem sporo. Niektóre naznaczone gorzką tkliwością:

Libra to mój ulubiony kwiat, ulubiony zapach, ulubiony kolor - to nie moja miłość, tylko coś, co mi się ze wszystkiego pod słońcem podoba najwięcej. Mógłbym ją zanudzić na śmierć, mówiąc jej o tym, powtarzając jej wciąż to samo. Libro droga, która mnie znów okłamujesz, znów odkładasz nasze spotkanie! Czy nie pamiętasz, żeś mi kiedyś powiedziała: „Nikt mi nie mówi tego co ty”. I nikt na pewno tego nie czuje ${ }^{111}$.

Inne pretensjami ${ }^{112}$, niepewnością ${ }^{113}$, tęsknotą $^{114}$, a nawet chęcią zemsty ${ }^{115}$.

Związek z Librą, pełen rozstań i powrotów, trwa co najmniej sześć lat, aż do śmierci Lechonia $^{116}$.

Ostatnie zapisy z Dziennika nie pozostawiają wątpliwości, że ich autor zmagał się $\mathrm{z}$ depresją. Świadczą o tym liczne wpisy na temat wariacji hipochondrycznych ${ }^{117}$,

[w:] tamże, s. 185; wpis z 20 stycznia 1954 r., [w:] tamże, s. 295; wpis z 24 września 1954 r., [w:] tamże, s. 456; wpis z 8 lipca 1955 r., [w:] tamże, s. 657; wpis z 3 sierpnia 1955 r., [w:] tamże, s. 672; wpis z 1 września 1955 r., [w:] tamże, s. 688; wpis z 28 września 1955 r., [w:] tamże, s. 704; wpis z 29 i 30 września 1955 r., [w:] tamże, s. 704; wpis z 18 października 1955 r., [w:] tamże, s. 714; wpis z 7 grudnia 1955 r., [w:] tamże, s. 743; wpis z 30 grudnia 1955 r., [w:] tamże, s. 755; wpis z 30 marca 1956 r., [w:] tamże, s. 816.

${ }^{104}$ Wpis z 13 sierpnia 1953 r., [w:] tamże, s. 185.

${ }^{105}$ Wpis z 1 września 1954 r., [w:] tamże, s. 450-451.

${ }^{106}$ Wpis z 30 grudnia 1953 r., [w:] tamże, s. 278.

${ }^{107}$ Wpis z 21 kwietnia 1953 r., [w:] tamże, s. 98.

${ }^{108}$ Wpis z 15 kwietnia 1956 r., [w:] tamże, s. 824; Gabriela Wielgosińska, przyjaciółka Lechonia i Aubreya Johnstona, zob.: B. Dorosz, Nowojorskie tajemnice życia i śmierci Jana Lechonia, s. 197.

${ }^{109}$ Wpis z 4 stycznia 1953 r., [w:] tamże, s. 17.

${ }_{110}$ B. Dorosz, Nowojorskie tajemnice życia i śmierci Jana Lechonia, s. 200.

${ }^{111}$ Wpis z 23 maja 1955 r., [w:] tamże, s. 627.

${ }^{112}$ Wpis z 14 kwietnia 1955 r., [w:] tamże, s. 605.

${ }^{113}$ Wpis z 1 kwietnia 1955 r., [w:] tamże, s. 598.

${ }^{114}$ Wpis z 4 kwietnia 1955 r., [w:] tamże, s. 599.

${ }^{115}$ Wpis z 7 kwietnia 1955 r., [w:] tamże, s. 601.

${ }^{116}$ Wpis z 23 marca 1956 r., [w:] tamże, s. 811. 
a także traktujące o zażywaniu ,pigułek na ekscytację i sen”118, o lęku przed starością („starość to nie naturalny proces przyrodniczy, to tragedia" ${ }^{, 19}$ ), niekończącym się najgorszym dniu w życiu (,Jestem zbity, jakbym walczył z jakimiś demonami - i pewno walczyłem. Dzisiaj jest lepiej, bo nie mogło być gorzej" "120 ; „piątek trzynastego jest zły, ale czwartek i środa nie były lepsze" ${ }^{, 121}$ ), maskowaniu smutku ${ }^{122}$, myśli o śmierci ${ }^{123}$, ale i chwytaniu się idei siły wyższej, upatrywaniu w niej nadziei („Boże, dobry Boże, nie opuszczaj mnie!”"124; „Można na zawsze znaleźć w swej inteligencji, woli, sercu coś, co pomoże nam w walce $\mathrm{z}$ życiem, $\mathrm{z}$ ludźmi. Ale na walkę z sobą — jest tylko modlitwa" ${ }^{\prime 125}$ ). Ostatnie miesiące Lechonia, jeśli traktować literalnie Dziennik, to nieustanne zmaganie się z sobą i zmierzanie ku nieuchronnemu końcowi.

Już po tragicznym odejściu pojawiają się głosy świadczące o tym, że maskowanie, o którym wspomina Lechoń, nie było skuteczne. Przywołany wcześniej list Smosarskiej do Grydzewskiego jest dowodem na to, że Leszek albo szukał pomocy, albo werbalizował - niekiedy wprost — swoje zamiary. Irena Lorentowicz wspomina, że tuż przed śmiercią pisał do niej o swoim złym samopoczuciu i apelował, aby się pospieszyła, jeśli chce go zobaczyć. Zabił się w dniu jej przyjazdu do $\mathrm{NY}^{126}$. Maria Kuncewiczowa przypomina sobie ostatnią z nim rozmowę telefoniczną: ,»Proszę się za mnie nie modlić. Ja nie jestem taki, jak mówią. Może nie lepszy. Ale inny. Może nie gorszy. Tylko inny«. Położył słuchawkę"127. Aleksander Janta ${ }^{128}$ dodaje, że w kwietniu 1956 roku Lechoń miał kryzys i mówił o samobójstwie ${ }^{129}$. Dlaczego zatem nikt w porę nie powstrzymał Lechonia przed tą decyzją?

${ }^{117}$ Wpis z 2 czerwca 1954 r., [w:] tamże, s. 384; wpis z 26 lipca 1954 r., [w:] tamże, s. 426; wpis z 28 sierpnia 1955 r., [w:] tamże, s. 686; wpis z 1 września 1955 r., [w:] tamże, s. 687.

${ }^{118}$ Wpis z 25 lutego 1954 r., [w:] tamże, s. 315; wpis z 6 kwietnia 1954 r., [w:] tamże, s. 341; wpis z 13 maja 1954 r., [w:] tamże, s. 368; wpis z 14 maja 1954 r., [w:] tamże, s. 369; wpis z 19 sierpnia 1955 r., [w:] tamże, s. 681; wpis z 16 kwietnia 1956 r., [w:] tamże, s. 825.

119 Wpis z 29 czerwca 1955 r., [w:] tamże, s. 652; wpis z 16 lipca 1955 r., [w:] tamże, s. 662; wpis z 29 lipca 1955 r., [w:] tamże, s. 669.

${ }^{120}$ Wpis z 10 sierpnia 1954 r., [w:] tamże, s. 436; wpis z 18 lipca 1955 r., [w:] tamże, s. 663; wpis z 16 sierpnia 1955 r., [w:] tamże, s. 679; wpis z 17 sierpnia 1955 r., [w:] tamże, s. 680; wpis z 20 sierpnia 1955 r., [w:] tamże, s. 681; wpis z 21 sierpnia 1955 r., [w:] tamże, s. 682; wpis z 2 września 1955 r., [w:] tamże, s. 688; wpis z 28 października 1955 r., [w:] tamże, s. 720; wpis z 31 października 1955 r., [w:] tamże, s. 721; wpis z 1 listopada 1955 r., [w:] tamże, s. 722; wpis z 9 lutego 1956 r., [w:] tamże, s. 782; wpis z 10 lutego 1956 r., [w:] tamże, s. 782; wpis z 25 marca 1956 r., [w:] tamże, s. 812; wpis z 20 kwietnia 1956 r., [w:] tamże, s. 827; wpis z 2 maja 1956 r., [w:] tamże, s. 835; wpis z 16 maja 1956 r., [w:] tamże, s. 845; wpis z 24 maja 1956 r., [w:] tamże, s. 849; wpis z 25 maja 1956 r., [w:] tamże, s. 850.

${ }^{121}$ Wpis z 13 kwietnia 1956 r., [w:] tamże, s. 824

${ }^{122}$ Wpis z 21 kwietnia 1956 r., [w:] tamże, s. 828; wpis z 22 kwietnia 1956 r., [w:] tamże, s. 829.

${ }^{123}$ Wpis z 13 marca 1955 r., [w:] tamże, s. 585; wpis z 3 maja 1955 r., [w:] tamże, s. 615.

${ }^{124}$ Wpis z 7 kwietnia 1956 r., [w:] tamże, s. 821; wpis z 8 kwietnia 1956 r., [w:] tamże, s. 821; wpis z 9 kwietnia 1956 r., [w:] tamże, s. 822; wpis z 22 i 23 kwietnia 1956 r., [w:] tamże, s. 829; wpis z 17 maja 1956 r., [w:] tamże, s. 845; wpis z 27 maja 1956 r., [w:] tamże, s. 850.

${ }_{125}$ Wpis z 29 maja 1956 r., [w:] tamże, s. 851.

${ }^{126}$ I. Lorentowicz, Odludki i poeta (1972), [w:] Wspomnienia o Janie Lechoniu, s. 251.

${ }^{127}$ M. Kuncewiczowa, Casus Lechoń (1972), [w:] Wspomnienia o Janie Lechoniu, s. 156.

${ }^{128}$ Aleksander Stanisław Janta-Połczyński (1908-1974), polski prozaik, poeta, dziennikarz, publicysta, tłumacz, podporucznik kawalerii Wojska Polskiego, kolekcjoner, bibliofil, posiadacz wielu „białych kruków”.

${ }^{129}$ A. Janta, „O dwa palce od serca czulem sępa szpony” (1957), [w:] Wspomnienia o Janie Lechoniu, s. 216-230. 
Po raz kolejny wkraczamy na teren niejednoznaczności. Hemar cytuje poetę: „Im dłużej żyję — mówił Lechoń - tym więcej czuję w sobie wdzięczności za każdy dzień życia, za samo szczęście istnienia, za samą radość oddychania, słuchania, patrzenia" ${ }^{\text {"130. }}$. Ciąg dalszy Hemarowych wspomnień to zapewnienie, że kto mógł, starał się pomagać Leszkowi, ,podając go sobie z rąk do rąk”. Nie było to łatwe: Lechoń to szukał pomocy, to przed nią uciekał; prosił o spotkanie, na które nie docierał; tyle razy przechodził i wychodził z kryzysów, że znieczulał tym swoich przyjaciół, którzy traktowali to jako zło oswojone ${ }^{131}$. Ostatnie spotkanie $\mathrm{z}$ Hemarem, środowa audycja z w Radiu Wolna Europa „Teatr na emigracji”, stało, według autora wspomnień, pod znakiem Lechoniowej dekoncentracji: poeta mylił się, gubił słowa, nie mógł znaleźć odpowiednich fraz $^{132}$. Inaczej owo spotkanie zapamiętał Marek Rudzki ${ }^{133}$ — według niego Lechoń wyglądał źle (blady, mizerny, spocony, trzęsły mu się ręce), ale udawało mu się skoncentrować. „Analizując głos poety — przesłuchiwałem kilkakrotnie tę taśmę - nie wyczuwało się w nim niepokoju, wzburzenia — widać, że potrafił się opanować"134.

Nawet Wierzyński, o którego czułej opiece i nieustannym lęku o Lechonia wspomina Hemar ${ }^{135}$, nie był świadom ostateczności kroków przyjaciela. Tak wspomina wydarzenia sprzed lat:

Zdumiewające było to, jak potrzebował ludzi, stosunków, spotkań, wizyt, wiadomości. U nikogo nie wyczułem takiego głodu ekscytacji, ruchu, świata. Każdemu miał coś do powiedzenia, wszystkich potrafił rozśmieszyć. Jego humor i dowcip, podobnie jak u Tuwima i Słonimskiego, był niewyczerpany. Mimo to popadał w depresję i już wówczas nabrał zwyczaju, który nie opuścił go do końca życia, aby powtarzać, że nie ma talentu i pytać, czy nie widać tego w pisaniu. Nikt nie odgadnie, ile w tym było kokieterii, a ile prawdziwego niepokoju. Przy jego niespotykanej inteligencji i ogromnych zdolnościach, niepewność siebie wydawała się najbardziej niespodziewanym cierpieniem tego dwudziestoletniego Werthera.

Pewnego ranka dowiedziałem się, że Lechoń targnął się na swoje życie. Zażył w nocy dużą ilość weronalu, obudził jednak swego brata śpiącego w swoim pokoju i to go uratowało. Wypompowano mu żołądek, przewieziono do szpitala św. Łazarza, gdzie go znalazłem na ogólnej sali. Leżał z rozpiętą na piersiach koszulą, pokłuty od zastrzyków. Miał czerwoną twarz i dyszał głośno. Patrzyłem na niego w osłupieniu, nie mogłem uporządkować myśli. Mówił często o samobójstwie, skarżył się na wyczerpanie nerwowe, zapowiadał, że nic już nie napisze i że to koniec wszystkiego. Ale zaraz po takich wyznaniach wpadał w inny nastrój, strzelał dowcipami, zaśmiewał się do rozpuku. Depresje jego mijały bez widocznego śladu, makabryczne groźby wydawały się czymś w rodzaju przekomarzania. I oto teraz leżał walcząc ze śmiercią ${ }^{136}$.

\footnotetext{
${ }^{130}$ M. Hemar, List o Lechoniu (1956), [w:] Wspomnienia o Janie Lechoniu, s. 198.

131 Tamże, s. 198.

132 Tamże, s. 199.

${ }^{133}$ Marek Rudzki (1929-?), ekonomista, tłumacz, redaktor, współpracownik RWE. Publikował w „Kulturze”, „Zeszytach Historycznych”, „Twórczości”.

${ }^{134}$ M. Rudzki, Lechonia poznatem pod fortepianem (1996), [w:] Wspomnienia o Janie Lechoniu, s. 293, przypis 18 .

${ }^{135}$ M. Hemar, List o Lechoniu, s. 198; również i ta przyjaźń byłą wystawiona na próbę o konflikcie wspomina Lechoń w listach do Grydzewskiego, np. z 15 lutego 1955 r., [w:] M. Grydzewski, J. Lechoń, Listy 1923-1956, t. 2, s. 346; po 21 lutego 1955 r., [w:] tamże, s. 351; wpis z 11 lutego 1955 r., 12 lutego 1955 r., 16 lutego 1955 r., 17 lutego 1955 r., [w:] J. Lechoń, Dziennik, t. 3, s. 564-568.

${ }^{136}$ K. Wierzyński, Z „Pamiętnika poety”, s. 47-48.
} 
Józef Wittlin przekonywał, że Lechoń „był zakochany w życiu” ${ }^{137}$. Iwaszkiewicz diagnozuje, że mimo przywiązania do życia nie opuszczała go myśl o śmierci. $Z$ drugiej strony, komentuje nieco ironicznie, czy nie jest to cechą konstytutywną nas wszystkich $?^{138}$ Hanna Mortkowicz-Olczakowa dodaje, że otrzymała autoironiczny list, będący pokłosiem nieudanej próby samobójczej i kuracji psychiatrycznej w zakładzie leczniczym dra Piltza w Krakowie; Lechoń pisał w nim: „Samobójstwo nieudane jest nietaktem towarzyskim i denat potem bardzo się wstydzi”"139. W Dzienniku Lechonia pod datą 30 czerwca 1954 roku znajdziemy wpis: „Zabił się młody Andrzej Znamięcki, syn Leszka i Zosi Pietrabissa. [...] Andrzej był bardzo pięknym chłopcem, bystrym, inteligentnym [...]. Straszna rzecz odebrać sobie życie. Biedny Andrzej!"140.

Zdzisław Czermański, notabene przyjaciel Lechonia, nazywa go neurotykiem i hipochondrykiem ${ }^{141}$. Przyznaje, że dostawał listy pożegnalne, które jednak wysyłane były w liczbie tak dużej, okraszone dodatkowo licznymi autogroźbami, że finalnie znieczuliły adresata ${ }^{142}$. Lechoń lubił, według Czermańskiego, smutek, a jednocześnie wymagał ciągłej opieki kogoś, kto ów smutek rozwieje ${ }^{143}$. „Wszystkie sposoby w walce ze śmiercią zawiodły. Mówi się, że gdyby nie był tak samotny jak był, toby żył. Nie wierzę. $\mathrm{Z}$ tą samotnością było mu dobrze i źle tak samo jak ze sławą. Spadła na niego za wcześnie, ucieszyła, ale też na resztę życia pozbawiła spokoju"144.

9 czerwca 1956 roku Czermański pisze do Grydzewskiego:

Drogi Mieciu,

zapewne już od wczoraj wiesz, co się stało. Wydaje mi się, że powinieneś zwrócić się do Janty z prośbą, aby zebrał wszystkie możliwe do osiągnięcia informacje na temat śmierci Leszka. Ostatni lunch na krótko przed śmiercią miał Leszek z niejakim p. Bejtmanem. (Podobno był zdenerwowany i ręce mu się trzęsły, ale też żartował). W kieszeni Leszka policjant znalazł kartkę z nazwiskiem dra Jachimowicza. Leszek był pacjentem dra Jachimowicza od wielu lat. Jachimowicz miał powiedzieć policji, że nie widział Leszka już od kilku tygodni. Ale jestem prawie pewny, że widział go dz. Józef... nazwiska nie pamiętam — przyjaciel pp. Falenckich. Podaję Ci nazwiska osób, które dużo go ostatnio widziały — u których nawet spał, bo nie chciał być sam: Państwo R. Rathausowie, Stanisława Nowicka. Prócz tego należałoby zwrócić się po informacje do gen. W. Kowalskiego, ppłk. Janusza Ilińskiego, Jerzego Krzywickiego, Zofii Rajchmanowej. Ja widziałem Leszka dziewięć dni temu na kolacji u pp. Krzywickich. Wyglądał trochę lepiej - miał zdrowszy kolor twarzy, ale był zgasły i choć mówił, robił to jakby po to, żeby się wciągnąć w rozmowę i zagadać złe samopoczucie. Od państwa Krzywickich wyszliśmy razem. W autobusie pytał mi się, co widać w jego twarzy. - Czy widać duże zmiany - czy widać melancholię. (Zmiana w wyglądzie Leszka w ostatnich kilku miesiącach była uderzająca. Schudł, miał twarz zmęczoną, zestarzałą, poruszał się ciężko). Rozstałem się z nim na przystanku autobusowym. Bywało, że przejęty jego wyglądem, wypytywałem go, co mu jest - ale tego wieczoru nie badałem go, bo wydawał mi się zdrowszy, choć okropnie smutny,

Pozdrawiam Cię serdecznie,

Zdzisław Czermański

\footnotetext{
${ }^{137}$ J. Wittlin, Śmierć i śmiech (1957), [w:] Wspomnienia o Janie Lechoniu, s. 178.

${ }^{138}$ J. Iwaszkiewicz, Lechoń, s. 61.

${ }^{139}$ H. Mortkowicz-Olczakowa, Wspomnienie o Janie Lechoniu, s. 142.

${ }^{140}$ Wpis z 30 czerwca 1954 r., [w:] J. Lechoń, Dziennik, t. 3, s. 406-407.

${ }^{141}$ Z. Czermański, O Leszku, s. 110.

${ }^{142}$ Tamże, s. 111.

${ }^{143}$ Tamże, s. 131.

144 Tamże, s. 133
} 
Ze wspomnianym w liście Aleksandrem Jantą-Połczyńskim pojednał się Lechoń na dwa tygodnie przed śmiercią; w 1948 roku, czyli w roku powojennej podróży Janty do Polski, której pokłosiem stał się tom reportaży, Lechoń zerwał z ich autorem kontakty, demonstrując w ten sposób swój stosunek do nowo odrodzonej Polski i jej admiratorów.

Wincenty Bejtman ${ }^{145}$ był bodaj ostatnią osobą, która widziała Lechonia przed jego samobójstwem. To z nim prawdopodobnie jadł lunch, omawiając i planując swój najnowszy film.

Jan Jachimowicz ${ }^{146}$ to zaufany lekarz psychiatra oraz przyjaciel Lechonia. Za jego namową Serafinowicz zaczyna przyjmować leki psychotropowe, od których się w końcu uzależnia. 21 marca 1950 roku pojawia się Dzienniku zapis: „Mam nadzieję, że to tylko paliatyw, dopokąd mnie inne zastrzyki nie wzmocnią - bo jak dotąd tak i do końca nie będę sobie pomagał sztucznymi podnieceniami, raz na zawsze postanowiwszy sobie nie być ich niewolnikiem czy dłużnikiem"147.

Z Falenckimi widzi się na pewno 19 maja 1956 roku, zapisując w Dzienniku: „Znów dzień szalonego smutku, coraz nowych komplikacji. Pojechałem na wieś do Falenckich. Cudnie, ale tym smutniej"148.

Rudolf Rathaus ${ }^{149}$ był zaprzyjaźnionym z Lechoniem dyplomatą i ekonomistą; jego żona, Maria Rathausowa, należała do Komitetu Organizacyjnego „Wieczoru Jana Lechonia”, wystawionego 24 kwietnia 1955 roku w Central Hight School of Needle Trades w Nowym Jorku. 28 lutego 1956 Lechoń odnotowuje: „Wczoraj siedziałem do pierwszej u Rathausów, piłem i śpiewałem, i - jak zawsze potem - głowy, a zwłaszcza nóg, nie czuję ${ }^{\text {"150. }}$

Stanisława Nowicka-Chylińska ${ }^{151}$ to nie tylko aktorka, pieśniarka, ale i teozofka, znana z umiejętności jasnowidzenia i daru przepowiadania (dar ów potwierdza autor Dziennika 19 marca 1950 roku $^{152}$ ). Na niecałe dwa tygodnie przed śmiercią Lechonia wysyła do niego list:

Wtorek 29 maja 1956. Kochany mój Leszku! Wiesz dlaczego piszę? Po prostu chcę Ci powiedzieć, że wiem, jak się czujesz. To samo dzieje się ze mną i nieomal wszystkimi ludźmi. Różnica leży w sposobie reagowania. Ludzie mniej uduchowieni czują wyraźny lęk, niepokój, aż do bólów fizycznych włącznie [...].

Leszku — bardzo Kochany - zaklinam Cię na wszystko, co masz najświętsze nie pozwól, aby niemoc wzięła górę nad Tobą. Sam czujesz najlepiej, że nie wolno Ci opuszczać rąk, bo przeznaczeniem Twoim jest zwycięstwo, a nie porażka. Masz tyle do zrobienia i nie dla siebie, a dla innych. Po to jesteś powołany do życia. Właśnie Tobie nie wolno paść w połowie drogi, bo masz jeszcze przed sobą długie i owocne życie, a stan obecny jest przejściowy! Jesteś wystawiony na próbę i musisz, musisz przezwyciężyć zmorę, która Cię opanowała! Leszuniu, wierz mi, że pół serca dałabym, aby Ci pomóc. Tak bym chciała, abyś spojrzał moim okiem na to, żeby dobry Bóg i Matka Boska Częstochowska pomogli $\mathrm{Ci}$ - modlę się o to i wierzę, że czerwiec, od 6go począwszy, da Ci możność powrotu do równowagi i obudzi nowe myśli i pomysły. Po-

${ }^{145}$ Księga gości Jana Lechonia, s. 103; Wincenty Bejtman (?-1992), filmowiec.

${ }^{146}$ Jan Jachimowicz (1902-?), nowojorski lekarz, przyjaciel Lechonia, nazywany przez niego „opiekuńczym aniołem”.

${ }^{147}$ Wpis z 21 marca 1950 r., [w:] J. Lechoń, Dziennik, t. 1, s. 246.

${ }^{148}$ Wpis z 19 maja 1956 r., [w:] J. Lechoń, Dziennik, t. 3, s. 846; Władysław Falencki (?-1990), finansista, filantrop, mąż Karin Tiche-Falenckiej — aktorki.

${ }^{149}$ Rudolf Rathaus (1900-1968), ekonomista, dyplomata.

${ }^{150}$ Wpis z 28 lutego 1956 r., [w:] J. Lechoń, Dziennik, t. 3, s. 794.

151 Stanisława Nowicka, pseudonim Sylwia Nowicka, Stanisława Sowińska, Stacha Nowicka (1905-1990), polska śpiewaczka, aktorka filmowa, teatralna i tancerka kabaretowa.

${ }^{152}$ Wpis z 19 marca 1950, J. Lechoń, Dziennik, t. 1, s. 244. 
wiem Ci szczerze, że imponujesz mi swoją postawą, gdyż wiem, jaki wkładasz w to wysiłek. [...] Serdecznie Cię całuję. Twoja Stacha ${ }^{153}$.

Lechoń 2-3 czerwca 1956 roku spędził u Nowickiej kilkanaście godzin; dwa dni po wspomnianej w liście dacie odbiera sobie życie.

O generale Wincentym Kowalskim ${ }^{154}$ wspomina Lechoń w Dziennikach dwukrotnie: 16 sierpnia 1953 roku chwali jego ostry, pozbawiony uprzedzeń zmysł dowódcy, a 22 czerwca 1955 roku relacjonuje jego opowieść o majorze Brzozie ${ }^{155}$.

Janusza Ilińskiego opisuje: „ma grzeczność nieuniżoną i wrodzoną, która przypomina najlepsze dawne czasy i każe myśleć o nich z westchnieniem żalu" "156.

Jerzemu Krzywickiemu ${ }^{157}$ zadedykował Lechoń wiersz Ojców; to o nim pisał:

jest zupełnym fenomenem jako rodzaj umysłowości. Jego ścisłość myślenia, matematyczność i jeśli tak można powiedzieć, instynkt filozoficzny, są zupełnym wśród Polaków unikatem. Nie wyobrażam sobie, żeby Tatarkiewicz np. mógł był dać równie precyzyjnie omówienie tak skomplikowanych i wielostronnych procesów myślowych, jak L'Homme révolté Camusa. Zarazem ma on czucie literackie, poetyckie, bez którego nie można przeniknąć do żadnego dna - filozoficznego tak samo. Czemuż ten fenomenalny umysł jest zarazem fenomenalnym leniuchem? Czyżby dlatego po prostu, że jest Polakiem ${ }^{158}$.

Pomimo imputowanego lenistwa Krzywicki wszedł w skład komitetu, który podejmował starania o zabezpieczenie spuścizny Lechonia. Porządkował też jego mieszkanie przed oddaniem go pod opiekę Polskiego Instytutu Naukowego w Nowym Jorku ${ }^{159}$. To on w końcu był współinicjatorem (razem z Felicją Lilpop-Krance) rozmów na temat pochówku Lechonia w Polsce (ostatecznie ekshumacja oraz przeniesienie szczątków Lechonia do Lasek pod Warszawą nastąpiło 11 maja 1991 roku) ${ }^{160}$.

O Zofii Rajchman czytamy 22 maja 1951 roku:

Droga Zosia Rajchman tak mi mądrze i ciepło obrzydzała mój pesymizm, że ból znieczulił się jak pod jakimś balsamem. Było to wszystko to akurat, co chciałem słyszeć, a co Zosia wyczuła swoim niezawodnym szóstym zmysłem. Bardzo, bardzo jestem jej wdzięczny ${ }^{161}$.

${ }^{53}$ Księga gości Jana Lechonia, s. 156.

${ }^{154}$ Wincenty Kowalski (1892-1984), generał brygady Wojska Polskiego.

${ }^{155}$ Wpis z 23 czerwca 1955 r., [w:] J. Lechoń, Dziennik, t. 3, s. 648.

${ }^{156}$ Wpis z 16 lipca 1950 r., [w:] J. Lechoń, Dziennik, t. 1, s. 349; Janusz Iliński (18961961), pułkownik Wojska Polskiego, dyplomata, żołnierz armii rosyjskiej.

${ }^{157}$ Jerzy Krzywicki (1917-2005), ps. Jerzy Rawicz, historyk filozofii, profesor, thumacz, kierownik Polskiej Sekcji Radia Wolna Europa.

${ }^{158}$ Księga gości Jana Lechonia, s. 137.

${ }^{159}$ Wspomina o tym Beata Dorosz: „W dniach 10-12 VII 1956 prof. Krzywicki przebywał w mieszkaniu Lechonia, przeglądając i porządkując porozrzucane przez policję papiery. Chodziło także o znalezienie testamentu poety, spisanego w szpitalu nowojorskim w przeddzień operacji w 1946 r. w obecności Kazimierza i Michała Kranców jako świadków, w którym Lechoń rzekomo decydował, iż wszystkie rzeczy po jego śmierci mają być rozdane wśród przyjaciół. Dokument ten nie został odnaleziony i zgodnie z postanowieniem Komitetu Opieki nad Spuścizną Lechonia pieczę nad wszystkim, co poeta pozostawił, przejął PIN. W różnych czynnościach porządkowych uczestniczył także, obok prof. Krzywickiego, Mieczysław Sierpiński, pracownik Instytutu", B. Dorosz, Archiwum Jana Lechonia w Polskim Instytucie Naukowym w Nowym Jorku. Redakcja z badań, Pamiętnik Literacki 1999 z. 3, s. 168.

${ }^{160}$ Ksiegga gości Jana Lechonia, s. 137.

${ }^{161}$ Wpis z 22 maja 1951 r., [w:] J. Lechoń, Dziennik, t. 2, s. 135; Zofia Rajchman z d. Małecka, uwieczniona m.in. na portrecie Witkacego z $1927 \mathrm{r}$. 
Czermański 14 czerwca 1956 roku w liście do Grydzewskiego podejmuje niejako przerwany, acz jakże istotny wątek:

[...] Leszka pochowaliśmy we wtorek. Zabił się sam bez żadnych wątpliwości. Powodem głównym była (tak trzeba to przyjąć) jego przeszłość homoseksualna wywleczona obecnie przy jego staraniach o obywatelstwo. Według tego, co Kaziowi wiadomo sędzia, który miał zaprzysiąc Leszka — znalazł w jego papierach sprzed lat dawny donos F.B.I. na niego (podobno „Mika” Nowińskiego). Dużo, a może i wszystko powinien na ten temat wiedzieć Besterman, bo on podobno na prośbę Leszka interweniował w tej sprawie. Dobrze byłoby, gdyby Besterman powiedział wszystko, co wie, bo dopiero wtedy moglibyśmy starać się ocenić, czy ten wypadek (czy wpadunek) był do przetrzymania, czy też - (znając Leszka i wiedząc coś niecoś o tutejszych inwestycjach) — był nie do zniesienia. Leszek w ostatnich miesiącach wyglądał jak człowiek chory i tylko domyślać się można, jakie przechodził męki. Choć są osoby, u których Leszek sypiał ostatnio, które mówią, że takiej męki nie mogłyby więcej razem z nim przeżywać. Mieszkanie swoje nazywał domem pogrzebowym — bał się być w nim sam i sypiał nieraz i sypiał nieraz po trzy noce z rzędu u znajomych.

Mówił ostatnio o samobójstwie, ale Leszek o samobójstwie mówił dużo razy i zawsze jakby tylko po to, żeby się nim zająć. Znieczulił nas tym gadaniem, tym bardziej, że nigdy dotąd nie miał wyraźnych - z zewnątrz - powodów do odebrania sobie życia. Byłoby to straszne, gdyby okazało się, że do tej desperackiej śmierci mogłoby nie dojść, gdyby ktoś umiał go uspokoić. Ale Leszek żądał nieraz nieprawdziwej odpowiedzi na nieprawdziwe pytanie. Jakżesz można było mu coś radzić i uspokajać go, skoro nie znało sie prawdziwego powodu jego niepokoju! Zwierzał się ostatnio nieraz różnym paniom - podobno mówił im wszystko - czy mogły go uspokoić — trudno sądzić. Tym razem byłem pewny, że Leszek był bardzo wyczerpany nerwowo. Takiego wyrazu przygnębienia nigdy na jego twarzy nie widziałem. Ale ponieważ mówił dużo o cukrzycy - jego schudnięcie i zmęczony wygląd tłumaczyłem sobie częściowo tą chorobą. Od długiego już czasu widać było, że go coś ogromnie niepokoi i myślałem zrazu, że to może podatki, że nabroił coś i boi się sądu.

Podobno skoczył z 14 piętra. Uszkodził sobie prawą stronę twarzy i połamał nogi. Czy można być pewnym, że zrobił to $\mathrm{w}$ chwili szału? Z restauracji, w której jadł obiad, przeszedł czy przejechał kilka bloków do hotelu Henry Hudson. Tam windą na górę. To trwało. Przeżyliśmy tu kilka okropnie smutnych dni i nocy. Byłem zawsze pewny, że Leszek wszystkich nas przeżyje. Być na pogrzebie Leszka to przeżyć coś, co jakby nigdy nie miało się stać.

Ja osobiście uważam, że Leszek był w wielkiej depresji jeszcze przed tą sprawą w urzędzie emigracyjnym. (Stał się jak nigdy dotąd wyczulony na punkcie swojej kariery i pozycji literackiej. Była to obsesja - zawiść o innych sukcesy — znałem ją dobrze, ale nie w takim stopniu - obawa - ciągła o wszystko obawa. Nawet sukces satyr Hemara przeżył jak osobiste niepowodzenie. Kazia - według mnie dobrego kolegę — zawsze bardzo obgadywał - na ostatniej kolacji z nim, a u młodych pp. Krzywickich też przy nich. Dużo innych przykładów depresji Leszka mógłbym Ci podać).

Samotność w dużym stopniu przyczyniła się do tego, co zrobił. (Chłopak był ciągle ten sam - nie wiem, czy stale. Dużo z nas znało go od wielu lat. Amerykanin. Jest od jakiegoś czasu z wycieczka w Europie - dlatego zapewne Leszek był ostatnio bez grosza).

Widać wszyscy przecenili siłę życiową Leszka, bo choć zmieniony był okropnie i rozpaczał, i groził samobójstwem, prawie nikt nie wierzył w to, że może on to zrobić Kazio widział go trzy dni przed śmiercią, rozmawiał z nim i nie przeczuł tego, co się stało. Wiadomość o śmierci Leszka zaskoczyła go tak jak innych.

Pozdrawiam Cię serdecznie, Zdzisław

Pozdrów ode mnie bardzo serdecznie Julka Sakowskiego ${ }^{162}$

${ }^{162} \mathrm{AE}$ AW, sygn. AE/AW/XLII, Korespondencja, list Czermańskiego do Grydzewskiego z 14 czerwca 1956 r., 
„Mika” (Mieczysław) Nowiński umiera 3 grudnia 1950 roku. O donosie - w nieco zawoalowany sposób — pisze Lechoń:

Umarł dzisiaj tzw. „Miecio” Nowiński, bardzo zabawna i malownicza figura z warszawskiego bruku. Zresztą umarł na pewno zniszczony przez nieprzystosowanie się do tego powietrza. Był on jakiś czas administratorem „Tygodnika Polskiego” i wtedy dając folgę swojej manii plotkarskiej, która bez świadomych intencji ocierał się o szyderstwo, bardzo mi dużo kłopotów narobił. Byłoby śmieszna pozą zapominać o tym, skoro nieraz przeklinałem go w duchu i skoro jego namiętność zawsze bardzo złośliwych, a nie zawsze dobrych dowcipów była mi szczególnie niemiła. Ale trudno nie myśleć teraz, że nawet $\mathrm{w}$ tym plotkarstwie było coś ze zdegenerowanego przywiązania do polskich, do warszawskich spraw i ludzi. I poza tym umarł - jak tylu Polaków w Ameryce - właściwie samotny po ciężkiej walce z ciężkim polskim losem. To jest to b e n e , które chcę o nim opowiedzieć ${ }^{163}$.

Wspomniany Władysław Besterman ${ }^{164}$ odegrał istotną rolę w zabiegach Lechonia o naturalizację: począwszy od 1952 aż do 1956 roku, kiedy to Lechoń zdawał przed komisją egzamin ze znajomości historii USA ${ }^{165}$.

Egzamin z przyjaźni zdał z pewnością pozdrawiany przez Czermańskiego Julek Sakowski ${ }^{166}$ - choć znajomość $z$ Lechoniem przechodziła przez różne fazy — to po śmierci Leszka zajął się, wraz z żoną, Stefanią, zredagowaniem przeszło dwuipółtysiąca nieczytelnego niekiedy rękopisu Dziennika. W owym diariuszu, pod datą 27 listopada 1951 roku, czytamy zaś: „Zawsze wiedziałem, że Julek nie jest tylko widzem, cieszę się, że wyszło z niego to, co przeczuwałem moją czułą przyjaźnią. I co więcej — pisze on tak, jak ja myślę, że powinno się pisać. Po prostu swoimi słowami — to, o co chodzi”"167.

Jaki jest klucz do śmierci Lechonia? Czy zabiła go samotność? A może brak pokory ${ }^{168}$ czy — jak nazywa to Czermański — tęsknota do osiągnięć? ${ }^{169}$ Czarnecka jako główny powód podaje strach przed deportacją, która

[...] uzasadniona jego homoseksualizmem, byłaby w jego własnym pojęciu skandalem — katastrofą jeszcze większą niż stoczenie się w otchłań nędzy. Byłoby to rozbicie budowanego przez lata obrazu samego siebie — tak w oczach innych, jak i jego własnych. Byłoby to złamaniem fanatycznie wręcz wyznawanego przez Lechonia zakazu ujawniania tego, co intymne, odmienne ${ }^{170}$.

Ten, który kochał życie, estetyzujący poeta, zafundował sobie i innym to, na co nie byli gotowi. Kuncewiczowa wspomina:

\footnotetext{
${ }^{163}$ Wpis z 3 grudnia 1950 r., [w]: J. Lechoń, Dziennik, t. 1, s. 480-481.

${ }^{164}$ Władysław Besterman (1903-1974), dyplomata. Przed wojną pracował w Agencji Iskra na stanowisku kierownika działu politycznego, był też warszawskim korespondentem United Press of America. W czasie wojny zajmował stanowisko attaché prasowego Ambasady RP w Waszyngtonie. Po wojnie pozostał na emigracji i był wysokim urzędnikiem Kongresu; pracował w Committee on Immigration and Naturalization przy Izbie Reprezentantów oraz był stałym doradcą Komisji Prawniczej, a także (1951) głównym doradca Komisji Izby Reprezentantów do Badania Spraw Uchodźców. Po przejściu na emeryturę zamieszkał w Genewie.

${ }^{165}$ Ksiega gości Jana Lechonia, s. 104.

${ }^{166}$ Juliusz Sakowski (1904-1977), dyplomata, eseista, współpracownik „Wiadomości Literackich".

${ }^{167}$ Wpis z 27 listopada 1951 r., [w:] J. Lechoń, Dziennik, t. 2, s. 300.

${ }^{168}$ Wpis z 27 sierpnia 1954 r., [w:] J. Lechoń, Dziennik, t. 3, s. 447.

169 AE AW, sygn. AE/AW/XLII, Korespondencja, list Czermańskiego do Grydzewskiego z 24 marca $1966 \mathrm{r}$.

${ }^{170}$ B. Czarnecka, Ruchomy na szali wagi. Lechoń homotekstualny, s. 219.
} 
Ostatni raz widziałam Lechonia w trumnie. Po skoku z osiemnastego piętra ${ }^{171}$ czaszkę miał sklejoną i połataną. Na twarzy, zamiast krwi, wosk i szminka. Leżał w masie kwiatów, król tragiczny bez pasa słuckiego na żałobną stronę, Herostrates, który zniszczył siebie. Ludzie przychodzili z biur i z domów, tak jak stali, w różnokolorowych ubraniach. Oglądali poetyczną kukłę, spuszczali oczy i odchodzili, szepcąc, każdy do swojej prozy $^{172}$.

Niektórzy szeptali, inni zdawali się krzyczeć. Do tych ostatnich zalicza się Malczewski, przez lata wspierany przez Lechonia, ratowany z opałów, teraz — bez ostrzeżenia pozostawiony samemu sobie.

Śmierć miał straszną. Wszystko czym mnie ratował okazało się pustym dźwiękiem. Tak jakby pisząc do mnie pozbawił się żywotnej treści. Myśli rozsypały się w proch, bezsilne, umarłe. Gdy losy niosły mu zagładę, nie miały litości nad człowiekiem tak bardzo kochającym życie w każdym objawie. Bał się śmierci i tak bardzo jej nie chciał.

A przecież wyszedł jej naprzeciw. Wielki, ciężki, niezgrabny ${ }^{173}$.

To krótkie epitafium zdaje się bolesnym krzykiem rozczarowanego człowieka: oto zawiódł ten, który powinien być skałą, a zamiast tego pewnego dnia o skałę się rozbił. I owszem, śmierć miał straszną, ale jeszcze bardziej zatrważające jest życie, które po sobie zostawił.

Niedokończone i nieoczywiste.

\section{LITERATURA}

Archiwum Emigracji, Archiwum „Wiadomości”, Korespondencja, sygn. AE/AW/XLII, AE/AW/ CXCIV, AE/AW/CCXCI.

Czarnecka B., Ruchomy na szali wagi. Lechoń homotekstualny, Torun 2013.

Dorosz B., Archiwum Jana Lechonia w Polskim Instytucie Naukowym w Nowym Jorku. Redakcja z badań, „Pamiętnik Literacki” 1999, z. 3.

Dorosz B., J. Lechoń, Z. i R. Malczewscy, Coraz trudniej żyć, a umrzeć strach. Listy 1952-1955, Biblioteka Więzi, t. 215, Warszawa 2008.

Dorosz B. (oprac.), Księga gości Jana Lechonia, Torun 1999.

Dorosz B., Lechoń i Tuwim - dzieje trudnej przyjaźni, Warszawa 2004.

Dorosz B., Lechoń nowojorski: w setna rocznicę urodzin poety, Warszawa 1999.

Dorosz B., Nowojorskie tajemnice życia i śmierci Jana Lechonia, „Teksty Drugie” 2004, nr 3. Giedroyc J., Gombrowicz W., Listy 1950-1969, oprac. A. S. Kowalczyk, Warszawa 2006.

Gombrowicz W., Dziennik 1957-1961, Kraków 1986.

Grydzewski M., Iwaszkiewicz J., Listy 1922-1967, oprac. M. Bojanowska, Warszawa 1997.

Grydzewski M., Lechoń J., Listy 1923-1956, t. 1-2, oprac. B. Dorosz, Warszawa 2006.

Kowalski S. J., Jan Lechoń jako redaktor i publicysta w okresie nowojorskim, Lublin 1996.

Księga gości Jana Lechonia, oprac. B. Dorosz, Torun 1999.

Lechoń J., Dziennik, t. 1 (30 sierpnia 1949-31 grudnia 1950), Warszawa 1992.

Lechoń J., Dziennik, t. 2 (1 stycznia 1951-31 grudnia 1952), Warszawa 1992.

Lechoń J., Dziennik, t. 3 (1 stycznia 1953-30 maja 1956), Warszawa 1993.

Lilpop-Krance F., Powroty, Warszawa 2013.

Listy Lechonia do Anny i Jarosława Iwaszkiewiczów, „Życie Literackie” 1982, nr 1.

${ }^{171}$ Por. list Czermańskiego z 14 czerwca 1956 r. (s. 197 tutejszej publikacji): „Podobno skoczył z 14 piętra".

${ }^{172}$ M. Kuncewiczowa, Casus Lechoń, s. 156.

${ }^{173}$ Rafał Malczewski, Śpiew (1957), [w:] Wspomnienia o Janie Lechoniu, s. 234-235. 
Miłosz C., Abecadło Miłosza, Kraków 1997.

Rogowski G., Skazane na zapomnienie. Polskie aktorki filmowe na emigracji, Warszawa 2017.

Rubinstein A., Wielki poeta, przyjaciel i brat, „Wiadomości” 1956, nr 31.

Sadkowska-Mokkas L., Warszawa skamandrytów, Warszawa 2016.

Stępień M., Wśród emigrantów, Kraków 2007.

Tomasik K., Homobiografie, Warszawa 2014.

„Wiadomości” 1957, nr 23 (584).

Wspomnienia o Janie Lechoniu, zebrał i oprac. P. Kądziela, Warszawa 2006.

„Życie Warszawy” 1996, nr z 6-7 lipca, dodatek.

\section{SURPRISING LECHOŃ}

Surprising Lechon was inspired by the reading of unpublished letters of Smosarska, Grydzewski and Czermański to Lechoń, which are stored at the Archives of Emigration in Torun. What emerges from the study of the letters is a portrait of a terribly interesting man, who was, however, full of contradictions, secrets, and ambiguities. The letters direct us towards other documents (books, articles, recollections, published letters), situating the poet in a new perspective.

KEY WORDS: Lechoń, suicide, recollections, letters, emigration

SŁOWA KLUCZOWE: Lechoń, samobójstwo, wspomnienia, listy, emigracja 